\title{
DENGUE INFECTION IN PARACAMBI, STATE OF RIO DE JANEIRO, 1990-1995
}

\author{
Rivaldo Venâncio da Cunha, Renato C. Maspero, Marize P. Miagostovich, \\ Eliane S.M. de Araújo, Daniele da C. Luz, Rita M.R. Nogueira \\ e Hermann G. Schatzmayr
}

\begin{abstract}
A seroepidemiological survey was carried out during 1994 in the municipality of Paracambi, state of Rio de Janeiro. Haemagglutination inbibition test positivity was detected in 145 out of 370 (39.2\%) schoolchildren. The frequency of positive test by sex was 53.8\% (78/145) female and 46.2\% (67/145) male. Distribution by age showed the increasing of antibody posivity in older children. Strains of dengue virus type 1 and dengue virus type 2 were isolated before (1990) showing the co-circulation of both serotypes in that area. The bouse index infestation of Aedes albopictus and Aedes aegypti has been determined.
\end{abstract}

Key-words: Dengue virus. Seroepidemiological survey. HAI antibodies.

Dengue virus activity has been demonstrated in Rio de Janeiro since 1986 when dengue virus type 1 (DEN-1) was first isolated15. Four years later, another serotype, dengue virus type 2 (DEN-2) was introduced12 and since then both strains co-circulate causing outbreaks and even large epidemics in the state with increased transmission associated with the rainy season 13 .

Paracambi is a municipality with approximately 40.000 inhabitants, located $80 \mathrm{~km}$ from Rio de Janeiro6, being a periurban city with own characteristics. The county has a small urban area with environments conditions that allow natural breeding of Aedes aegypti and Aedes albopictus. Because of its geographic position, the presence of both vectors and dengue activity, we carried out a seroepidemiological survey to determine the prevalence of dengue virus infection in the area. This paper describe the virological, clinical and entomological data of a five years (1990-1995) study in Paracambi.

Disciplina de Doenças Infecciosas e Parasitárias, Departamento de Clínica Médica, Universidade Federal de Mato Grosso do Sul, Campo Grande, MS, Curso de PósGraduação em Medicina Tropical, Laboratório de Flavivírus, Departamento de Virologia do Instituto Oswaldo Cruz/FIOCRUZ, Rio de Janeiro e Secretaria de Saúde de Paracambi, RJ.

Financial support: CNPq and Fundação Banco do Brasil. Address to: Prof. Rivaldo Venâncio da Cunha. R. Dr.Armando Cunha 483, Bairro Jardim Villas Boas, 79051-040 Campo Grande, MS. E mail: rivaldoc@alanet.com.br Recebido para publicação em 31/07/96.

\section{MATERIALS AND METHODS}

Virology and serology. Virus isolation was attempted from human acute phase sera as described before 11 by inoculation into a of clone $\mathrm{C} 6 / 36$ of $A e$. albopictus cells9. Virus isolates were typed by indirect fluorescent antibody test (IFAT) using serotype-specific monoclonal antibodies?.

IgM capture enzyme-linked immunosorbent assay (Mac-Elisa) was performed for routine serodiagnosis using serotype specific antigens DEN-1 and DEN-2, as described previously10.

Serological survey. Blood samples from 370 schoolchildren with age ranging from 4 to 16 years old were obtained in public schools of Paracambi by fingertip puncture and collected on filter paper discs (Whatman № 1). The sample size was based on the prevalence of haemagglutination inhibition antibodies detected in previous inquires carried out in others municipalities of the state 345 . The confidence level of $95 \%$, a sampling error of $10 \%$ and a refusal possibility of $25 \%$ were considered. Parents or responsible for children gave a formal consent for blood collection. The haemagglutination inhibition test (HAI) was carried out according the method of Clarke \& Casals, 19582. Blood samples were treated with kaolin (Sigma) and goose erythrocytes for remotion of non-specific inhibitors and natural haemagglutinins, respectively.

Antigens. DEN-1 (Mochizuki strain) and DEN-2 (New Guinea strain) antigens were prepared by intracerebral inoculation of suckling 
Cunha RV, Maspero RC, Miagostovich MP, Araújo ESM, Luz DC, Nogueira RMR, Schatzmayr HG. Dengue infection in Paracambi, State of Rio de Janeiro, 1990-1995. Revista da Sociedade Brasileira de Medicina Tropical 30:379-383, set-out, 1997.

mice and extracted by sucrose-acetone method2.

Vectors house index. House index for Ae. aegypti and Ae. albopictus were determined 14 during 1991 to 1994 by the Secretary of Health of Paracambi all over the municipality which includies 13 localities.

\section{RESULTS}

Virological and clinical findings. Laboratorial data obtained from 1990 to 1995 are shown in Table 1. In 1990 both serotypes (DEN-1 and DEN-2) were isolated and the remaining cases were confirmed by serology (IgM). Twentyone cases of dengue haemorrhagic fever were reported between April 1990 to November 1991. No dengue cases were confirmed by laboratory during 1992 to 1994, although dengue cases have been reported in these years (Figure 1).
Table 1 - Laboratorial confirmation on dengue suspected cases in Paracambi, RJ, 1990-1995.

\begin{tabular}{|c|c|c|c|}
\hline \multirow[t]{2}{*}{ Year } & \multicolumn{2}{|c|}{ № } & \multirow{2}{*}{$\begin{array}{c}\text { Dengue virus } \\
\text { isolation }\end{array}$} \\
\hline & positive & studied & \\
\hline 1990 & 20 & 52 & DEN-1- 7 e DEN-2 - 5 \\
\hline 1991 & 12 & 103 & - \\
\hline 1992 & 0 & 9 & - \\
\hline 1993 & 0 & 0 & - \\
\hline 1994 & 0 & 20 & - \\
\hline 1995 & 5 & 30 & DEN-2 - 2 \\
\hline
\end{tabular}

Serological survey. HAI antibody titres equal or greater than $1 / 20$ to DEN-1 and/or DEN-2 was detected in 39,2\% (145/370) of the tested samples. The geometric mean of antibody titres was $1 / 75$ for DEN-1 and $1 / 30$ for DEN-2 (Table 2).

The absolute and relative frequencies of positive tests by age group and when compared to extreme age groups show statistically significant differences $\left(\chi^{2}=15,07 ; p<0,005\right)$.

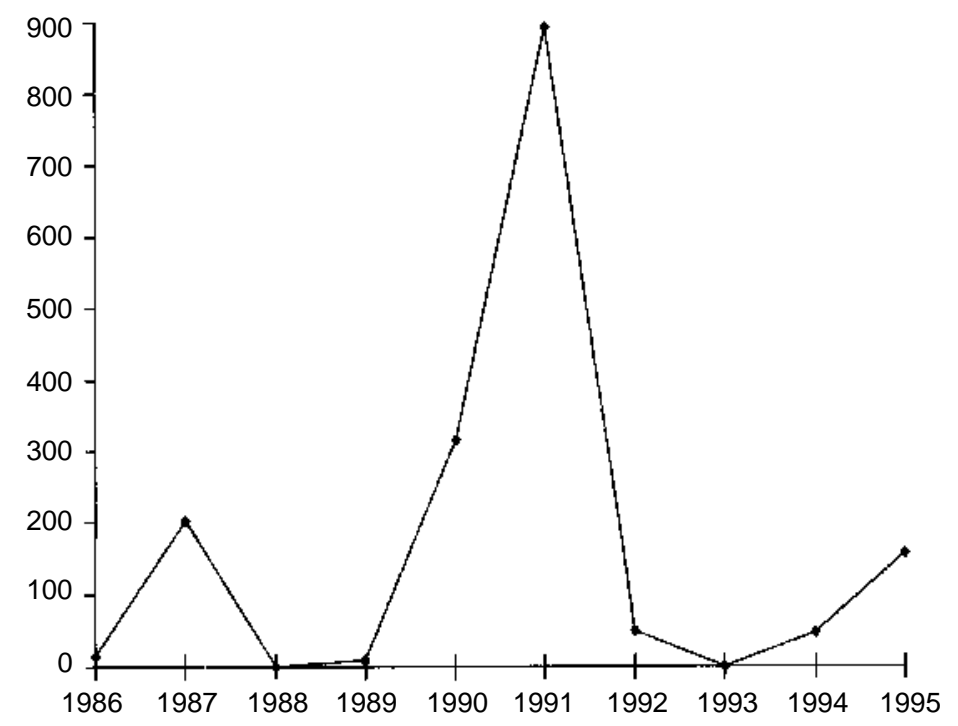

Source: Secretary of Health/Municipality of Paracambi, RJ.

Figure 1 - Dengue reported cases in Paracambi, RJ, 1986-1995.

The absolute and relative frequencies of positive tests by sex did not show statistically significant differences; nevertheless the total result shows a slight predominance of the positivity for the female group (Table 3 ).
Entomological findings. In the beginning of 1991 when entomological surveillance was established house index of Ae. aegypti ranged from $2 \%$ to $7 \%$ in some localities (Lages, Sabugo, Centro). After this program, in 1994, 
Cunba RV, Maspero RC, Miagostovich MP, Araújo ESM, Luz DC, Nogueira RMR, Schatzmayr HG. Dengue infection in Paracambi, State of Rio de Janeiro, 1990-1995. Revista da Sociedade Brasileira de Medicina Tropical 30:379-383, set-out, 1997.

the index declined from $0.0 \%$ to $2.0 \%$. During the same period all over localities showed higher house index of Ae. albopictus ranging from $0.6 \%$ to $7.4 \%$.

\begin{tabular}{|c|c|c|c|c|}
\hline \multirow{2}{*}{$\begin{array}{c}\text { Antibody } \\
\text { titres }\end{array}$} & \multicolumn{2}{|c|}{ DEN-1 $^{*}$} & \multicolumn{2}{|c|}{ DEN-2*** } \\
\hline & $\mathrm{n}^{\circ}$ & $\%$ & $\mathrm{n}^{\circ}$ & $\%$ \\
\hline $1 / 20$ & 27 & 20.0 & 35 & 52.2 \\
\hline $1 / 40$ & 35 & 25.9 & 24 & 35.8 \\
\hline $1 / 80$ & 28 & 20.7 & 8 & 12.0 \\
\hline $1 / 160$ & 26 & 19.3 & - & - \\
\hline $1 / 320$ & 11 & 8.1 & - & - \\
\hline $1 / 640$ & 4 & 3.0 & - & - \\
\hline $1 / 1280$ & 4 & 3.0 & - & - \\
\hline Total & 135 & 100.0 & 67 & 100.0 \\
\hline
\end{tabular}

Table 3 - Age and sex distribution of dengue HAI antibodies in Paracambi, RJ, 1994.

\begin{tabular}{|c|c|c|c|c|c|c|c|c|c|}
\hline \multirow{3}{*}{$\begin{array}{c}\text { Age } \\
\text { (in years) }\end{array}$} & \multicolumn{9}{|c|}{ Sex } \\
\hline & \multicolumn{3}{|c|}{ female } & \multicolumn{3}{|c|}{ male } & \multicolumn{3}{|c|}{ total } \\
\hline & positive & studied & $\%$ & positive & studied & $\%$ & positive & studied & $\%$ \\
\hline$\leq 10$ & 12 & 47 & 25.5 & 12 & 55 & 21.8 & 24 & 102 & 23.5 \\
\hline $11-14$ & 39 & 91 & 42.8 & 28 & 70 & 40.0 & 67 & 161 & 37.9 \\
\hline$\geq 15$ & 27 & 59 & 45.7 & 27 & 48 & 56.2 & 54 & 107 & 50.5 \\
\hline Total & 78 & 197 & 39.6 & 67 & 173 & 38.7 & 145 & 370 & 39.2 \\
\hline
\end{tabular}

$\mathrm{P}=0,61351 ; \chi^{2}=0,98$

\section{DISCUSSION}

During DEN-1 epidemic (1986/1987) in the state of Rio de Janeiro, 217 dengue cases were notified in Paracambi, however laboratorial confirmation occurred only in 1990, when DEN-1 and DEN-2 viruses were isolated. In 1990/1991 the number of reported cases reached 1209 with a total of 21 cases of dengue haemorrhagic fever. As observed in the municipality of Rio de Janeiro and Niterói the disease was more severe after the introduction of DEN-2 virus 13 .

To study the prevalence of dengue infection after these outbreaks we adopted a sampling plan for the seroepidemiological survey that limited the generalization of the results to the whole population of the Paracambi municipality. Nevertheless the results obtained are acceptable to determine the serological profile of dengue infection in the studied population. On the other hand, if we consider that the introduction of dengue virus in this municipality is relatively recent (1986), being therefore all age groups susceptible to the virus, we can expect a prevalence of dengue infections in the other age groups close to that of the examined schoolchildren. Considering the seropositivity of $39.2 \%$ and the population of Paracambi, about 16.000 persons should have been infected in this municipality, since the introduction of dengue until the time that the present study was done.

Serological surveys in the municipality of Rio de Janeiro during 1986 and 1987 showed $24.9 \%$ and $45.5 \%$ of HAI antibodies for DEN-1 serotype 5 . In Niterói, others surveys detected $62.4 \%$ e $55.0 \%$ of seropositivity to $\mathrm{DEN}-1$ in 1987 and 1988, respectively 4 , and 66\% to DEN1 and/or DEN-2 in 1991/19923. All these serological surveys were carried out in schoolchildren. Our data are comparable with the results obtained in different areas, with the similar epidemiological aspects. At Cuba, two national serological investigations estimated in $44.5 \%$ the levels of HAI antibody after DEN-1 epidemic in 1978 and in $42.0 \%$ after DEN-2 epidemic in 198218.

Serological results, when related to sex, did not show statistically significant differences, although we detected a slight predominance of seropositivity for the female group. A small 
Cunba RV, Maspero RC, Miagostovich MP, Araújo ESM, Luz DC, Nogueira RMR, Schatzmayr HG. Dengue infection in Paracambi, State of Rio de Janeiro, 1990-1995. Revista da Sociedade Brasileira de Medicina Tropical 30:379-383, set-out, 1997.

positivity predominance for that group were observed in the all investigations cited before. An increasing of positivity related to age was seen but it is only statistically significant when compared to extreme age groups.

The geometric averages of antibodies titres were $1 / 75$ and $1 / 30$, to DEN-1 and DEN-2, respectively, and were similar to that found in 1987 and 1988 in Niteróít. Geometric averages of $1 / 182$ and $1 / 71$, to DEN-1 and DEN-2, respectively were detected in Niterói in 1991/19923. The ranging of geometric average could be explained by the elapsed time since the survey was carried out and the epidemic activity. Niterói seroepidemiological survey was carried out after the decline of epidemic and, by other hand, this study was done 3 years after the peak of epidemic in the state. Levels of HAI antibodies as high as 1/20000 was detected in several cases of dengue haemorrhagic in Niterói. Two years later those patients showed a significant decrease on HAI antibodies titers (1/160) (RMR Nogueira, data not published).

Low dengue activity between 1991 to 1994 agree with low house index of Ae. aegypti in spite of high level of Ae. albopictus house index in same period. Unfortunately the interruption on vectors measures control allowed again the dengue transmission in the area.

\section{RESUMO}

Um inquérito soroepidemiológico foi realizado em uma amostra de escolares, em 1994, no município de Paracambi, Estado do Rio de Janeiro. Positividade do teste de Inibição da Hemaglutinação foi detectada em 39,2\% (145/370) dos escolares pesquisados. A freqüência de positividade foi de $53,8 \%$ (78/145) para o sexo feminino e de 46,2\% (67/145) para o sexo masculino. A distribuição por faixa etária mostrou uma positividade crescente com o aumento da idade. Cepas do vírus dengue tipo 1 e virus dengue tipo 2 foram isoladas anteriormente (1990), mostrando a co-circulação de ambos os sorotipos na área. Os índices de infestação predial pelo Aedes aegypti e pelo Aedes albopictus foram determinados.

Palavras-chaves: Vírus Dengue. Inquérito Soroepidemiológico. Anticorpos Inibidores da Hemaglutinação.

\section{ACKNOWLEDGMENTS}

The authors are grateful to José da C. Farias Filho, José de Carvalho Filho, José Carlos Avelar and the staff of Municipal Secretary of Health, Paracambi, for technical assistance during the serological survey.

\section{REFERENCES}

1. Cantelar N. Dengue en el Caribe y las Américas artículo - revisión). (II Parte). Revista Cubana de Medicina Tropical 35:136-153, 1983.

2. Clarke DH, Casals J. Techniques for haemagglutination and haemagglutination - inhibition with arthropod - borne virus. The American Journal of Tropical Medicine and Hygiene 7:561-573, 1958.

3. Cunha RV, Dias M, Nogueira RM, Chagas N, Miagostovich MP, Schatzmayr HG. Secondary dengue infection in schoolchildren in a dengue endemic area in the state of Rio de Janeiro, Brazil. Revista do Instituto de Medicina tropical de São Paulo 37:517-21, 1995.

4. Dias M, Dias AMC, Figueiredo LTM. O dengue em Niterói - Inquérito sorológico em escolares. Revista da Sociedade Brasileira de Medicina Tropical 24 (supl II):116-117, 1991.

5. Figueiredo LTM, Cavalcante SMB, Simões MC. Dengue serologic survey of schoolchildren in Rio de Janeiro, Brazil, in 1986 and 1987. Bulletin of the Pan American Health Organization 24:217225, 1990.

6. Fundação Centro de Informações e Dados do Estado do Rio de Janeiro. Anuário Estatístico do Estado do Rio de Janeiro, 1987. Secretaria de Estado de Planejamento e Controle, Rio de Janeiro, 1988.

7. Gubler DJ, Kuno G, Sather GE, Velez M, Oliver A. Use of mosquito cell cultures and specific monoclonal antibodies in surveillance for dengue viruses. The American Journal of Tropical Medicine and Hygiene 33:158-165, 1984.

8. Guzman MG, Kouri GP, Bravo J, Calunga M, Soler M, Vasquez S, Venereo C. Dengue haemorrhagic fever in Cuba. I. Serological confirmation of clinical diagnosis. Transactions of the Royal Society of Tropical Medicine and Hygiene 78: 235238,1984 .

9. Igarashi A. Isolation of Singh's Aedes albopictus cell clone sensitive to dengue and chikungunya viruses. Journal General Virology 40:531-44, 1978.

10. Kuno G, Gomez, Gubler DJ. Detecting artificial anti-dengue IgM immune complexes using an enzyme-linked immunosorbent assay. The 
Cunha RV, Maspero RC, Miagostovich MP, Araújo ESM, Luz DC, Nogueira RMR, Schatzmayr HG. Dengue infection in Paracambi, State of Rio de Janeiro, 1990-1995. Revista da Sociedade Brasileira de Medicina Tropical 30:379-383, set-out, 1997.

American Journal of Tropical Medicine and Hygiene 36:153-159, 1987.

11. Miagostovich MP, Nogueira RMR, Cavalcante SMB, Marzochi KBF, Schatzmayr HG. Dengue epidemic in the State of Rio de Janeiro, Brazil: virological and serological aspects. Revista do Instituto de Medicina tropical de São Paulo 35:149-154, 1993.

12. Nogueira RMR, Miagostovich MP, Lampe E, Schatzmayr HG. Isolation of dengue virus type 2 in Rio de Janeiro. Memórias do Instituto Oswaldo Cruz 85:253, 1990.

13. Nogueira RMR, Miagostovich MP, Lampe E, Souza RV, Zagne SMO, Schatzmayr HG. Dengue epidemic in the state of Rio de Janeiro, Brazil, 1990-1991: Co-circulation of dengue 1 and dengue 2 . Epidemiology and Infection 111:163-170, 1993.

14. Pan American Health Organization. Dengue and dengue hemorrhagic fever in the Americas: Guidelines for prevention an control. Scientific Publication, $\mathrm{n}^{\circ}$ 548, Washington, 1994.

15. Schatzmayr HG, Nogueira RMR, Rosa APT. An outbreak of dengue virus at Rio de Janeiro. Memórias do Instituto Oswaldo Cruz 81:245-246, 1986. 